\title{
Feminist Perspectives on Education and Pedagogy: A Meta-Synthetic Insight into the Thought of Four American Philosophers
}

\author{
Dr. Khadija Alhumaid \\ Zayed University, UAE
}

Doi: 10.36941/ajis-2019-0003

\begin{abstract}
The present paper reports on the views of four prominent feminist intellectuals and philosophers (Maxine Greene, bell hooks, Christine Sleeter and Patti Lather) and how their ideas, coloured by their lifestyles, experiences, careers and beliefs, impacted the educational field. In common, these feminists championed the universal values of equality, freedom, pluralism using different educational and political stratagems. Together, they mapped new terrains of equity and fairness and anti-racist practices as social and educational practices. A free informed conscientious aesthetic and artistic imagination in addition to a multicultural approach to education are viewed as a salvation act from the taken-forgranted perceptions and routines as well as an emancipation of students' brains from race, class and gender prejudices. It is concluded that these ideas, if put into practice, are liable to improve education as they pay heed to taking care of marginalized women, enhancing democratic teaching and building a healthy educational climate where both teachers and students are connected to the wider community.
\end{abstract}

Keywords: feminism, educational theory, Maxine Green, bell hooks, Christine Sleeter, Patti Lather

\section{Introduction}

Recent years have seen a growing interest in investigating feminism and post-feminism as multifaceted theories in relation to works of art, narrative genres and ideological political discourse, as exemplified in several edited volumes, debates and articles. However, it is worthy of note that there is a paucity of studies relevant to the investigation of the feminist perspectives on education and pedagogy, in general.

In the introductory part of the current article, I will first provide an operational definition of 'feminism' then sum up in a chronological order the four waves feminism underwent as a sociopolitical movement. Next, I will briefly sketch the main building blocks of these four American philosophers/intellectuals' works to emancipate the human mind and the way they envision education from a feminist perspective to denounce forms of class, race and gender segregation as well as the masculine patriarchal domination. At the end, an analytical meta-synthetic comparison will be established in an attempt to pull these feminists' views together and scrutinise the global elements of convergence in their writings.

\section{Data}

In the present account of how some feminist works reshaped education and pedagogy, I drew on a corpus of 37 articles and 4 books written by four influential American feminist intellectuals and prolific writers as well as activists: Greene, Lather, Sleeter and Hook (more often referred to here as hook). For each of these four authors, an even sampling anthology of writings expressing various feminist views of each of the aforementioned philosophers was selected that ostensibly purports the 
general trends of thought and that might hopefully reflect the essence of their vision related to the socio-political scene as well as the educational one from multifaceted feminist perspectives.

The herein selected corpus of articles and books is not meant to be an exclusive illustration of these four feminists' ideas and general philosophy as they have already published a vast plethora of articles and books. It is also worthy of note that the arrangement of articles selected for the current study does not necessarily or chronologically represent any methodological motives other than to assemble certain fragmented pieces of thought to purport substantial guidelines and synopsis of these feminists' positions regarding certain issues such as education, race, gender and many more.

\section{Methodology}

The present article attends to the impact of feminism as a multidimensional concept on education using a meta-synthetic analysis based on a body of qualitative research and writings of four different intellectuals that, while operating within the field of feminism in their own way, had relatively adopted divergent stances in relation to education and desegregation. Though their concerns might differ and though they position themselves differently in relation to the topic, a meta-synthetic analysis is likely to identify the main trends and key ideas that permeated their works.

Jensen and Allen (1996) assert that a meta-analysis is 'a relatively new technique for examining qualitative research' and that Stern and Harris (1985) were the first to coin the phrase 'qualitative meta-synthesis' with reference to the amalgamation of a group of qualitative studies. Their aim was the development of an explanatory theory or model which could explain the findings of a group of similar qualitative studies (Walsh \& Downe, 2005, 204).

Schreiber et al (1989) and Sherwood (1999) contend that a meta-synthesis is more than a systematic review of the literature. It is 'bringing together and breaking down of findings, examining them, discovering the essential features, and, in some way, combining phenomena into a transformed whole' (Shreiber et al, 1989, 314). Therefore, the purpose of meta-synthesis is to develop new knowledge based on systematic attempts to analyse existing qualitative research findings of the phenomenon under study.

Put into other words, Erwin et al (2011) consider that a qualitative meta-synthesis is 'an intentional and coherent approach to analysing data across qualitative studies'. Moreover, 'it is a process that enables researchers to identify a specific research question and then search for, select, appraise, summarize, and combine qualitative evidence to address the research question'. This explains the fact that meta-synthetic studies primarily serve to 'integrating findings across qualitative studies to discover patterns and common threads within a specific topic or issue' (Erwin et al, 2011, 186).

Though this is not, by any means a comprehensive account of their philosophy, the scrutiny of the predominantly thematic analyses of feminism in connection with education inferred from the works of the four American feminist philosophers will hopefully show how feminism might be considered as a transformative proactive approach to liberating education, reshaping the plight of schools worldwide and transcending violence, unfairness and alienation in education.

\section{Background}

In studies dealing with feminism, it is quite noticeable that gender, race, color and male domination are customarily dealt with as the most prominent and driving themes that enflame debates amongst feminist writers and philosophers. However, attending to educational and pedagogical issues from feminist perspectives is not a common major concern to the point that Manjrekar $(2003,4577)$ noticed that 'It is somewhat surprising, then, and worthy of critical attention, why feminist engagements with the politics of knowledge, both in the academic arena and through activism, have bypassed the field of education in a larger sense and school education in particular'.

Hence, the central contention of this paper is to contribute new insights into the common understanding of the linkage between feminism and education and how feminism might reshape 
education on the levels of policies, curricula and instructional approaches towards more equity and justice. Moreover, this article intends to shed some light on how four revered feminist activists managed to nurture a ground for the actualization of freedom in order to break with the ordinary and the taken-for-granted prejudices in the educational arena.

\section{What is Feminism?}

Feminism is a highly contested term. Beasley (1999, ix) contends that "feminism's complexity and diversity provide obstacles to those wishing to gain a satisfactory grasp of its meanings". Broadly conceived, feminism, according to Haraway (1989:290 in Coffey \& Delamont, 2000, 1), 'seek[s] to explain and change historical systems of sexual difference, whereby 'men' and 'women' are socially constituted and positioned in relations of hierarchy and antagonism'. Feminism then has many meanings, not one. However, the general focus of feminism can be summed up in achieving gender equality at economic, political as well as social levels (Hawkesworth, 2006). This equality encompasses equal rights to vote, employment, equal payment, properties and lodging as well as education, etc. Feminists have also worked towards protecting females from rape, domestic violence and sexual harassment in addition to securing women's reproductive rights (access to legal abortions and using contraceptives) (Messer-Davidow, 2002). The encapsulation of feminism as laid down above does not represent one stage, however, since feminism, as is known today, has gone through many waves.

\subsection{Waves of Feminism}

\subsubsection{First Wave}

The first wave of feminism started in the late 19th century and early $20^{\text {th }}$ century as a reaction to the downgraded plight of women being treated as second rate citizens in male-dominated societies. In 1848, the Seneca Falls Convention promulgated a declaration of equality between men and women (Rampton, 2015) that advocated their right to vote (suffrage). Soon, some European countries, including Sweden, Finland and some states in western US granted women voting rights (DuBois, 1998). In 1904, the International Woman Suffrage Alliance was launched in Germany and it encouraged governments to give women full voting rights. Most European countries and colonies followed in giving women either partial or full voting rights from the 1910s to 1950s (Sneider, 2010). At the dawn of the $20^{\text {th }}$ century, most of the European nations took the initiative of granting women the right to vote namely Russia, Germany, Austria and the United Kingdom in 1918, Belgium in 1919, US and Canada in 1920, Ireland in 1928, and Spain in 1931, etc. (Martin, 2000).

\subsubsection{Second Wave}

The second wave of feminism started in the 1960s and lasted till 1990s (Rampton, 2015) in the midst of great social upheavals and big events, starting with the Civil Rights Movement that aimed at equality between white and black Americans mainly through pacifist and non-violent campaigns and protests (Carson, 2018). The Movement led to vast legal changes, including the passing of the Civil Rights Act of 1964 that outlawed discrimination "based on race, color, religion, sex, or national origin" in schools and employment (Transcript, 1964). While the first wave was dominated by white middle-class women in the west, the second wave was affected by the Civil Right Movement and, thus, many non-white faces in the west as well as in developing countries were in the lead. Accordingly, feminism at this stage took a more theoretical shape and called for the overthrow of sisterhood and "began to associate the subjugation of women with male domination with broader critiques of patriarchy, capitalism, normative heterosexuality, and woman's role as wife and mother" (Rampton, 2015). One result of this attitude was the emergence of radical feminists, who assumed that all women, irrespective of their racial, ethnic, class, age or cultural differences, were more similar to one another than to any man and that women had to take control over their bodies (Russell \& Carey, 2003). This explains the focus of feminism at this stage on women's sexuality as 
well as reproductive rights (i.e. using contraceptives, abortion, lesbian relationships, birth control) (Burkett, 2016; Rampton, 2015).

\subsubsection{Third Wave}

The third wave of feminism appeared in the 1990s (Rampton, 2015) and it came to complement what first and second wavers started. Indeed, many of the third-wave feminists are second-wavers' daughters. For instance, Rebecca Walker, an American feminist writer, and activist, is the daughter of the second-wave novelist Alice Walker, the author of the famous work of art 'The Colour Purple'. Although the third wavers inherited an important legacy from the second wavers, including university programs dedicated to women studies, journals, and magazines, that legacy was not as important as it was for the second wavers. This is due to the fact that the third wavers relied heavily on new technology, especially the Internet. New ezines (electronic magazines) and personal blogs changed the space for expression (Burkett, 2016). The focus of third-wave feminism as a postcolonial movement, according to Fisher (2013), was no longer on laws and political processes; rather, the focus was on individual identity. In addition, the third wave was no longer confined to any class, race or country; indeed, many third-wave feminists refused the term feminism, find it "limiting and exclusionary" and see feminism "global" (Rampton, 2015) because "women are of many colors, ethnicities, nationalities, religions and cultural backgrounds" (Fisher, 2013). This shows that the third wave of feminism emphasizes diversity and speaks for all women more blatantly than the first and second waves.

\subsubsection{Fourth Wave}

The fourth wave of feminism is the contemporary wave we are watching evolving and still developing and expanding. Rampton (2015) thinks that feminism is no longer a realm manipulated by women in the academia. To all intents and purposes, it has gone through public discourse because young women and men, mainstream press and politicians are all involved in talking about women's problems like rape, sexual harassment, domestic violence against women, wage differences, etc. from femininity to femaleness, feminism is sparking wide attention much similar to any global problem, with a clear focus on gender equity.

\section{Feminism and Education}

Feminism has undoubtedly fought, since its very beginning, for women's right to education and this led to women's greater access to education across the globe (Messer-Davidow, 2002). Feminists have not given women more places in schools alone; they have also succeeded in securing women specializations that used to be male-dominated for a long time, including science and technology. But what about education? Have feminists somehow impacted the educational field? The present article attempts to answer these two questions by shedding light on the insights of four feminists who have influenced education theory: Maxine Green, bell hooks, Christine Sleeter and Patti Lather.

\subsection{Maxine Greene}

Greene was born in 1917 and died in 2014. She received her Ph.D. from New York University in 1955 and taught at Teachers College at Columbia University for about 50 years. Her long life was a fruitful journey through which she was a vivid academic and writer interested in history, sociology, literature, and philosophy of education. She was known as a pioneering educational philosopher and the first female president of the Philosophy of Education Society (in 1967) and the American Educational Research Association (in 1984) (Weber, 2014). She is the author of many books, edited chapters, journal articles besides many talks and lectures, most of which centred on conceptions of aesthetic experience, imagination, multiculturalism, pluralism and the power within the individual, liberty (Weber, 2014), which duly made her a pioneering aesthetic educationalist. As 
an education philosopher, she was an ardent proponent of 'wide-awakedness' drawn from Alfred Shultz, a notion that consists in a 'plane of consciousness of highest tension originating in an attitude of full attention to life and its requirements' (Goldman, 2010, 7-8).

\subsubsection{Arts as source of Imagination}

Maxine Greene was one of the revered thinkers in the field of education and pedagogy. Her philosophy of aesthetic education was largely influenced by Sartre, de Beauvoir, Camus, Kierkegaard and Merleau-Ponty. From her vantage point, aesthetic education means 'the process of building students' cognition by exposure to the arts' (Goldman, 2010, 1). Greene (1967a, 1967b, 1968,1977 a, 1977b) posits that imagination has a huge role in arts education as it motivates teachers and students alike to see through others' experiences and learn from them indirectly. Imagination is 'the capacity to break with the ordinary, the given, the taken-for-granted and open doors to possibility. One way of describing it is as a "passion for possibility" (Greene, 2007, 1). Imagination, then, is not something negative; rather, it takes people outside their 'lived realities' and makes them able to connect with others, regardless of any difference on any basis (i.e. religion, gender, class, age, race). Further, imagination for Greene can be a solution to the boredom that many students feel in arts classes if teachers can imagine new possibilities and get students involved in arts based on imagination like drama classes or paint exhibitions (Greene, 2007).

Imagination is an essential part of accessing arts and activating consciousness to allow people to 'break through the cotton wool of daily life' and stave off stereotyped and absolutist ways of thinking. Arts have the merit of stimulating and releasing imagination. In the same vein, arts and imagination "can provide experiential opportunities" for both teachers and students "to see the world from multiple perspectives" (Kisaka \& Osman, 2013, 338). Hence, arts are a basic tool in learning as they "encourage a kind of thinking that best serves humankind" (Weber, 2014). Aesthetic education has the potential of arousing people to become 'more than passive onlookers', that is to release their imagination so as to be 'willing to engage [...] to wonder, to probe, to discern connections, to reach deeper, to seek out more and more' (Greene, 2011, 8) and not merely give credence to the realities of things as they are.

Greene $(1968,62)$ highlighted the need to make literature more meaningful to students caught in tides of alienation, faithlessness, and distrust'. A s such, thought-provoking arts have the potential to help people understand the world, which is a reason why teacher education should involve literary works and art; simply, because literature and art can help teachers educate children to take responsibility for our collective wellbeing by developing a conscious concern for the particular, the everyday, the concrete" (Kisaka \& Osman, 2013, p. 343).

\subsubsection{Education, freedom, democracy and responsibility}

Teaching children to be responsible for our collective wellbeing is deeply related to Greene's conceptions about the relationship between education, freedom, and democracy, all interrelated. While ascribing to the views of Paul Freire, Greene $(1971,253)$ knew that 'curriculum, from the learner's standpoint, ordinarily represents little more than an arrangement of subjects, a structure of socially prescribed knowledge' and that the job of schools is not only to prepare employees for the job market or the 'economic competitiveness'; rather, it is also to prepare them to be good citizens who can choose the principles of freedom and equality (Goodman \& Teel, 1998; Blanchard, 2010). But how can children be taught to be good citizens in schools?

Green complies with the view that education is a process of personal development or growth (Greene, 1967b, 272) in the same vein, she points out that, to forge a democratic educational policy-making, this has to foster universal education, pursuit of happiness, commitment to democracy, principles of freedom, and distributive justice (Greene, 1967a, 1967b, 2000, 2007).

The concept of 'functionalist model of education' assuming that society consists of actors who fulfil specific roles that support the survival of the whole of society is threaded throughout Greene's work. For her, 'schools, then and now, deliver content and measure proficiencies that are determined by economic concerns rather than a desire to holistically foster children's development 
as they grow into their potential' (Blanchard, 2010, 1).

\subsection{Bell Hooks}

Bell Hooks was an influential feminist literary theorist. Born in 1952 in Kentucky, south of the US, her real name is Gloria Jean Watkins, and she adopted the pseudonym bell hooks as a pen name after her great-grandmother to honor women's legacy, keeping the name in lowercase letters so that attention is paid to her message rather than to herself. Hooks' mother worked as a maid at whites' homes and her father was a janitor. She was raised up in a black neighbourhood and went to a segregated school before the desegregation of schools in Kentucky in the 1960s (Bell Hooks Biography, 2018). Hooks does not conceal the fact that she was lucky to be born in the 1950s because of the Civil Rights Movement and active feminist movement at that time (Williams, 2006). This harsh, segregated life that Hooks led might have boon one of the reasons why she got involved in defending equal rights of all people, especially black women, and this rendered her one of the well-known feminists all over the world. hooks received her BA from Stanford University in 1973, her MA from Wisconsin-Madison University in 1976 and her Ph.D. from the University of California, Santa Cruz in 1983. Hooks taught at many American universities, including Southern California University, Yale University, City College of New York and Berea College in Kentucky. Her works are centred on feminism, black feminism, the intersectionality of class, race, and gender in education, sexuality, history, sexuality, and media.

\subsubsection{Education and freedom}

Freedom, well-being and self-actualization are recurrent intertwined concepts upon which hooks' vision of critical educational philosophy is based. In most of her writings (hooks, 1965; 1993; 1995a; $1995 b)$ as well as in her seminal book 'Teaching to Transgress: Education as the Practice of Freedom', Hooks (1994) discussed the way freedom leads to successful education in its bidirectional manifestation, education as the practice of freedom and education as a reinforcement of domination. She herself went through the two types of education: the education that she enjoyed in a black, segregated school because it was the place where she had the opportunity of reinventing herself through ideas and the education she hated at a white school where she and her colleagues "soon learned that obedience, and not zealous will to learn, was what was expected of" them (hooks, 1994, 3).

One gets the sense that Hooks has always been concerned with a bias-free mode of education as she maintains that 'white supremacy, imperialism, sexism, racism, etc. have distorted education so that it has not been about the practice of freedom' (Hooks, 1993, 8). Hence, she ostensibly supports education as the practice of freedom, which involves teaching "in a manner that respects and cares for the souls of ... students" and makes them transgress race, class and gender boundaries (hooks, 1994, 13). Contrary to the education based on memorization and that converts students into machines, education as the practice of freedom - which hooks also calls progressive education (2003, xv) - means that students' voices "can be heard, their presence recognized and valued" (hooks, 1994, 185), which ultimately brings about creative students who can be good citizens. Education as the practice of freedom is a praxis that depends on the teachers' and learners' self-actualization, a process that empowers students to learn in a non-threatening, antidiscriminatory way. According to Specia and Osman $(2015,196)$, Hooks argues that teaching as a performative act is a catalyst that calls everyone to become more and more engaged on the path of change, invention and spontaneous shifts. Hence, "teaching was one of the most substantial forms of political resistance" (Bell Hooks Biography, 2018) that hooks took from feminist movements to the realm of academia and education.

In the same vein, the classroom is a potential source of liberation and not a source of constraint. All in all, Freedom in education for hooks, is a sine qua non for a relaxing and exciting classroom where students are heard, motivated to take part in community initiatives, empowered to work with the broad community where they live and be duly prepared for the job market as well as life in general. 


\subsubsection{Education and change}

The selected corpus of hooks' publications shows her struggle against estrangement and alienation especially in the field of education and pedagogy. For her, feminist pedagogy is, to all intents and purposes, an act of transformation of 'a more rather than less real' world. It is a revolutionary enterprise that delivers a twofold message, first, that attitudes towards gender, race, and class can change through a reconceptualization of the role of education and second, that education is a practice of freedom towards relinquishing the bonds with male domination especially in the teaching profession. Within this perspective, hooks seems to replicate the argument advanced by Freire (2005: 81) who wrote that 'Education as the practice of freedom--as opposed to education as the practice of domination--denies that we are abstract, isolated, independent, and unattached to the world; it also denies that the world exists as a reality apart from us."

Teachers practice democracy within classrooms by opening more inclusive learning spaces and conversing with students while respecting their different social origins and the cultural backgrounds they come from and sharing knowledge outside the classroom without supporting domination. If this is achieved, the classroom will be "a place that is life-sustaining and mindexpanding, a place of liberating mutuality where teacher and student together work in partnership" (hooks, 2003, xv). The lesson we learn from this approach is that educational institutions should ideally be places that nurture democratic action inside the classroom and that this approach in teaching will probably positively influence the outside world. hooks (1986a, 1986b, 1997) also touches upon the values of family, spirituality, and love in education. She believes that spirituality is, in essence, about caring for the souls of students and taking them away from the feelings of loneliness, despair, and frustration (hooks, 2003). hooks further reveals that healthy family relationships should be fostered so that children can succeed in their education. As for the academy and the world outside, hooks (2000, p. 5) believes that education has to be upheld as a rebellious act against the 'politics of domination' and a passionate engagement in unveiling 'incoherences in what appears to be strictly ordered'.

In brief, hooks' ideas about education can be generally looked at as holistic education or engaged education that ultimately empower students to transgress all boundaries, overcome all types of denomination, and help teachers to achieve self-actualization (hooks, 1994; hooks, 2003; Headley, 2008).

\subsection{Christine E. Sleeter}

A stern defender of multiculturalism, Christine E. Sleeter was born in 1948 in Oregon, US. She received her BA in Political Science from Willamette University in 1970, another BA degree in Secondary Education in 1972, her MA in Curriculum and Instruction from Seattle University in 1977, and her Ph.D. in Curriculum and Instruction from Wisconsin-Madison in 1981 (Sleeter, 2018). Sleeter worked as a learning disabilities teacher at a secondary school in Seattle following the desegregation of schools, and this made her interested in multicultural education. Then, she started teaching at many universities and has been a visiting professor at many universities inside and outside the US. Sleeter has had over 140 articles and 20 books published, centred on ethnic discrimination, racism, disability in education and intersectionality of gender, class, and race. Most of her work focuses on developing teachers' abilities to deal with diversity in educational settings. As one of the proponents of multiculturalism, Sleeter's biggest contribution to educational theory pertains to multicultural education -that is achieving equality among all students regardless of any basis (gender, class, race, religion, language, etc.).

\subsubsection{Multicultural education: problems}

One of the points that Sleeter has frequently stressed in many of her writings is multicultural education. She has always emphasized the need to consider culturally-responsive pedagogy in teacher professional preparation and in curriculum design. She thinks that focusing on promoting individualism and market competition-the core of neoliberalism - does not support 'empowered 
learning of diverse student populations in ways that culturally responsive pedagogy does' (Sleeter, $2011,8)$. However, the multicultural and bilingual approaches to teaching, which were adopted following the desegregation of schools in the 1960s, have mostly been substituted by standardized curricula that started in 1992 (Sleeter, 2011). The problem with these standardized curricula is that they are taught based on the language and experiences of English-speaking whites and with no consideration of the individual differences amongst students (Gutiérrez et al 2002). The reason for changing policies is not only following successful business models but "elite and white fear of losing [so-called] national and global hegemony" (Sleeter, 2011,12) as well. The results of insisting on teaching these curricula in this way to all students, white and non-white alike, are disastrous as is attested in the report issued by the Educational Testing Service (ETS, 2007) that evaluated the application of standardized curricula and found that the minority students are disadvantaged compared to white students in the major 14 experiences and conditions encouraging student achievement (measured in terms of child early development, the school environment and the home learning environment).

\subsubsection{Multicultural education: solutions}

Closely akin to hooks' claims, Sleeter believes in education as a pathway to freedom. In general, she assumes that education can lead to freedom or slavery in that 'it can be used to give future citizens the knowledge and ability to protect and advance their political rights and beliefs'. Similarly, it can be used to 'enslave citizens by shaping behavior and beliefs to conform to the needs of political power' (Sleeter, 1994, 31-32). With this in mind, she asserts that 'Multicultural education challenges school processes that reproduce inequality'.

In the US, standardized curricula bring about catastrophic results and state as well as national standardized tests are realities that cannot be ignored (Cabrera et al, 2014). As a solution to this dilemma, Sleeter believes that standards can "provide coherence by guiding teachers in what to teach at each grade level, reducing unnecessary redundancy, and making sure that there is a meaningful sequence of learning" (Grant \& Sleeter, 2012, 172), which can help teachers lead students to achieve highly on tests.

Standardization, on the contrary, "has adverse effects [sic] on students, teachers, and schools because it leads to bureaucratization and to a focus on low-level knowledge" (Sleeter, 2005, x). To solve this problem, Sleeter suggests a solution that can enable teachers to teach in a way that responds to students' different cultural backgrounds and, at the same time, help students acquire the skills required to perform well on standardized tests. Her solution relies on planning lessons around central ideas/concepts (regardless of subject or grade) and connecting content to these concepts. In fact, concepts are the ideas that should ideally be taken outside the class even if students forget the details (Wiggins \& McTighe, 1998, 10). Then, the skills and knowledge required should be decided so that concepts could be trimmed and re-written.

All of these steps can be carried out depending on state and/or national standards. Afterward, the multicultural aspects can be planned. Teachers should plan to put their (transformative) knowledge of the sociocultural backgrounds of their students as related to the concepts that should be taught into the curriculum and, afterwards, plan to test what students know or what knowledge/skills is/are worth, important and essential for them to know/comprehend and apply. Students should finally be assessed (Sleeter, 2005). Teachers' and students' input of their knowledge and experiences fosters engagement and understanding between them - a crucial step in teaching minorities and disadvantaged students. Starting planning from the central ideas/concepts and then moving to details, which is followed by Sleeter (2005), is what Wiggins and McTighe (1998) call backward design, which proves very useful in Sleeter's model to solve the standards vs. culturally responsive pedagogy problem. The proposed curriculum design can lead to filling the gap between races in academic achievement, putting an end to prejudice and stereotyping as well as establishing democracy and care within classrooms (Sleeter, 2008; Grant \& Sleeter, 2012). 


\subsection{Patti Lather}

Patti Lather is an Emeritus Professor at the Ohio State University. She received her BA in English from South Dakota State University in 1970, her MA in American Studies from Purdue University in 1972, and her Ph.D. in Curriculum and Instruction from Indiana University in 1983. She taught at many universities inside and outside the US. Lather is a prolific feminist writer published many books, edited chapters, and journal articles. She is concerned with feminist theory, feminist pedagogy, feminist research methodology, qualitative research, postmodern/post-structural theories, and scientific research in education (Patti Lather's Web Page, 2017). Lather is considered one of a few activists who contributed to feminist theory, particularly in teaching scientific research and how this scientific approach/methodology can be applied in schools. Because of her opinions of how women of all races should be empowered in academia and scientific research, she was thought to be black (Lather, 2012). Lather's work on methodology and her understanding of many types of philosophies, especially the relationship between philosophy and scientific research, have enabled her to write a lot about qualitative research then teach it in many graduate programs at many universities (Saugstad, 2007).

\subsubsection{Postmodernism and education research}

Lather believes in the nexus between 'postmodernism / poststructuralism / deconstruction' (1992, 88 ) and how it guides critical research and understanding of the challenging dominant paradigms in education. For her, postmodern means "the larger cultural shifts of a post-industrial, post-colonial era" (Lather, 1991, 4) that she sees suitable to be applied in academia. Lather sees that postmodernism can be a good tool in pedagogical research because it allows for enlarging the possibilities of critical social science and empowering pedagogy. By empowerment, she means "analysing ideas about the causes of powerlessness, recognizing systemic forces, and acting both individually and collectively to change the conditions of our lives" (Lather, 1991, 4). Explicating how postmodernism can be useful, Lather says that it really 'exacerbates an already felt erosion of basic assumption' and 'implodes the concepts of "disinterested knowledge" and the referential, innocent notions of language [...] to move away from positivism and to loosen the grip of psychologism on its theories and practices'. (1991, 6).

Lather (1991) believes that society is witnessing a shift away from being a knowable, factual and objective world and that knowledge is a result of the interaction between language, power, and meaning. Following a postmodern approach, she uses feminist research to support selfunderstanding and self-determination that can result in liberating language and power in education. She also reveals that it is too difficult to design a liberating curriculum for the disadvantaged, including women, within such society. Lather deconstructs modernity and finds that all modern philosophies (positivism, existentialism, phenomenology and critical theories) have all established what she calls control of knowledge. To develop curricula aimed at creating knowledge for teachers and researchers alike in the postmodern age, Lather suggests, existing curricula and beliefs (e.g. teachers being superior to students) should be first deconstructed before starting a democratic process characterized by co-operation and discussions that can lead to liberating disempowered students and teachers (Lather, 1991).

\subsubsection{Educational reform}

Lather (1992, 2004b in South End Press Collective, 1998) acknowledges to be influenced by critical pedagogy that was grounded in the works of Frankfurt School, Gramsci, and Paulo Freire and that ushered in the 1980s as a sort of "big tent" for educationists embarking on academic work for social justice finalities. She takes pride in being engaged in some sort of revolutionary critical feminist pedagogy. This is very clear in many of her writings (Lather, 1987; 1990; 2004a). As a feminist believing in science and out of her specialization in teaching education and her wide expertise at school management and reform in the US, she has always called for school reform. In doing so, she has always taken the stance of a brave feminist who criticized the 2001 'No Child Left Behind 
Act' that focused on core standards and academic achievement as unfair and cumbersome (Lather, $2004 \mathrm{~b})$. She claims that the outgrowth of this Act was but testing and accountability mania in addition to one-size-fits-all formulas.

As a methodologist-a person who does research on research (Lather, 1992, 87), Lather qualifies most of her work as 'critical inquiry' of systems of inequity such as classism, racism, and sexism based on gender. She posits that 'feminism supports the centrality of gender in the shaping of our consciousness, skills, and institutions as well as in the distribution of power and privilege' (Lather, 1992, 91). In the same vein, she opposes the governmental intervention in educational research, which has negatively affected reading education, math education, science education and professional development (Lather, 2004b). All alike, Lather denounces a big mistake committed at American schools; that is, studying "human activity in a way modeled after the assumedly cumulative, predictive and stable natural sciences" like "behaviorism, cognitivism, structuralism and neopositivism" (2004b, 760). As a solution to this problem and to achieve school reform, Lather (2004b) suggests that educational researchers apply social science in a way that can cope with the diversity of the social world, which may convince governments that natural-science methods (like adopting core standards in education) may not be good all the time when applied in education.

\section{A Comparative Perspective}

Thus far, to unravel the bonds and connections between these feminists' systems of thinking and major concerns, we attempted to sketch the insights of these four intellectuals in relation with education and pedagogy and spell out the main tenets and premises upon which they articulated their conceptions of feminism and how it could transform the common scene. In this final part, I have to do a contrastive meta-analysis whereby some of the common as well as distinctive broad epistemological guidelines of these feminist activists and philosophers are laid.

Jensen and Allen (1996) and Sandeslowski (1993) postulate that a synthesis of qualitative accounts is supposed to grab the essence of the phenomenon, presenting a way to achieve a "fuller knowing" to advance knowledge. Hence, as a preliminary remark, it is noticeable that at the exception of Maxine Greene who saw the feminist movement in its early inception and who experienced the four waves of feminism, Sleeter, Lather and Hooks lived in the eras of the second, third and fourth feminist waves with the resurgence of the women's movement in the sixties. This impacted, one way or another, their views of the role feminism plays in aligning the intransigent discriminatory and prejudiced practices towards social justice in the political, social and educational arenas.

All of them vociferously fought against the devaluation and oppression of women in the social public sphere as well as in the educational practices. They played a prominent part in bringing to the centre some of the peripheral concerns of the women's movement. These issues provided the impulse to their writings on gender, race and class discriminatory practices that governed the American society. Though aesthetic education, releasing imagination and multiculturalism took precedence in the writings of Greene and Sleeter respectively, the four reformist feminists attempted to alert the American society to the dilemmas of patriarchy -'the socially sanctioned power of men over women' (Lather, 1987, 27), social injustice, biased curricula and the taken-forgranted white supremacy that together pervaded people's social mores. These issues qualified by Lather (1987) as the 'absent presence' are but social and cultural constructs of power that serve to perpetuate a given social order and essentially male privileges. Hence, feminism ushered as a movement where a wide feminist critical consciousness was enshrined that soon turned into a farreaching political and ideological act of resistance.

The selected pool of publications reveals that there are certain inextricable common points of contention in the writings of the four feminists. Their primary concern was taking a stand against taken-for-granted social, political and educational practices. Consciousness-raising - synonymous of 'critical awareness' and wide-awakedness' - was the embodiment of a common backlash these four intellectuals took against the mainstream. Consciousness-raising is manifold in their writings as it is directed towards critiquing masculinity, patriarchal family (Lather, 1987, 1988, 1992, 2004b, 2009), racism, class elitism and sexism (Bell Hooks, 1986, 1993, 1995a, 1995b, 1995c), changing 
education, empowering imagination (Greene, 1977b, 1983, 1991, 2000a, 2007, 2011) and implementing multiculturalism (Sleeter, 1989, 1994, 1996, 2014, 2001, 2018).

These four feminist activists offered new insights and perspectives that are different from the normative ways of looking at the world. Together, they contributed to building a feminist pedagogy as an engaged and reflective approach that aims to promote the teachers' and students' well-being through an ongoing process of self-actualization and as a way of 'transgressing' against the conformity to 'the overwhelming boredom, disinterest, and apathy that so often characterizes the way people feel about the teaching and learning experience' (hooks, 1994, 10).

These four intellectuals succeeded also in their dissident work to walk the line between ideological political commitment and aesthetic advocacy and championed an educational orientation that would reconstruct the world. It is commonly upheld that feminism is not just a mere reaction to male domination and racial prejudice but a proactive transformative act that impacts the political, social and educational mores not only in America but worldwide. Bell hooks (1995a, 269) points out that 'masses of women and men will never convert to feminist thinking unless they can see ways that the practice of feminism positively transforms lives'. To come to grips with this end, Lather (1992) brought race, class, sexual orientation or gender to the forefront of her feminist inquiry as consciousness-shaping factors attempted primarily to unseat the 'scientific orthodoxy' in favour of 'a keen awareness of the limits of any new "one-best-way" approach to doing science'. Sleeter (1989) contends that multicultural education is a form of resistance to oppression. hooks mediates 'critical consciousness' and self-actualization while Greene thinks of 'wide-awakedness' as an intellectual act to liberate the imaginative potential of the learners through arts and creativity in order to be engaged in an emancipated understanding of race, power, sexism, oppression, alienation and coercive patriarchal domination. 'Without such an awareness', Green $(2000,12)$ posits, 'young people are liable to feel locked into a world others have constructed'.

\section{Conclusion}

It is clear that the four feminists whose insights have been discussed above have enriched educational theory and made available a vast literature that can be very useful for generations. It is also evident that, in Western societies, especially the United States where feminism has been very influential, these insights offered by Greene, hooks, Sleeter and Lather on education were the outgrowth of the clashes between Afro-Americans and white Americans towards eradicating all forms of 'interlocking systems of domination like sexism, racism, class oppression, imperialism, and so on' (Hooks, 1986, p. 126). The question now is: are the insights of these feminist scholars/educators universal; that is, can they be useful to other societies with different political regimes, limited natural resources, lack of democracy and lack of organized educational institutions, especially in developing countries in Africa and Asia?

Overall, it may be said that feminism gave new impetus to educational research and theory. It has proved a very good motivator for Greene, hooks, Sleeter and Lather who remained in the vanguard of social and educational reform paying heed to the marginalisation, subjugation and dehumanization of women. Each in their own way, they called for a 'revolution in mental health' so as the healthy spirits in society would be able to be engaged in a liberation struggle to end domination - as 'damaged spirits rarely choose liberation' (hooks, 1995a, 271).

The major convergent points of the four philosophers are reflected in mediating freedom, selfactualization, wide-awakedness and imagination to transgress schools and universities' alien reality. These consciousness-raising aesthetic and intellectual mechanisms are liable to establish democratic teaching, taking into account non-whites who do not speak English as a mother tongue and designing curricula that suit their needs, reforming the educational system in a way that benefits teachers and students alike, building ties between students and teachers at schools/universities and other ties between them and the wider community, etc. These assertions often repeated in the writings of the four feminists discussed above make it clear that it is still within the reach of feminism to offer more constructive contributions to education reform in the same way it has always contributed to setting social political and economic changes with eyes wide open on civil rights and human rights likewise. 


\section{References}

Beasley, Chris. 1999. What is feminism anyway? Understanding contemporary feminism. Sydney: Allen and Unwin.

Bell Hooks Biography 2018. In Encyclopaedia of world biography. Accessed 21 June 2018. http://www.notablebiographies.com/He-Ho/Hooks-Bell.html

Blanchard, Anne. 2010. "The Dialectic of Freedom by Maxine Greene." Journal of Educational Controversy, 5 (1), 1-4, Article 26.

Burkett, E. Augustus 2, 2016. Feminism. In Encyclopædia Britannica. Accessed 15 July 2018. https://www.britannica.com/topic/womens-movement

Cabrera, Nolan L. ; Jeffrey F. Milem; Osan Jaquette, \& Ronald W. Marx .2014. "Missing the (student achievement) forest for all the (political) trees: Empiricism and the Mexican American studies controversy in Tucson." American Educational Research Journal, 51(6), 1084-1118.

Carson, Clayborne. May 7, 2018. "American civil rights movement." In Encyclopædia Britannica. Retrieved from https://bit.ly/2kACitg

Coffey, Amanda \& Sara Delamont. 2000. Feminism and the classroom teacher: research, praxis, pedagogy. London: RoutledgeFalmer.

DuBois, Ellen Carol. 1998. Woman suffrage and women's rights. New York: New York University Press.

Erwin, Elizabeth. J.; Mary Jane Brotherson, \& Jean Ann Summers. 2011. "Understanding Qualitative Metasynthesis: Issues and Opportunities in Early Childhood Intervention Research." Journal of Early Intervention, 33 (3): 186-200. doi.org/10.1177\%2F1053815111425493

ETS (Educational Testing Service). 2007. "ETS education issues 2007." Accessed 3 July 2018. http://www.ets.org/Media/Education_Topics/pdf/candbrief2007.pdf

Fisher, J.A. 2013. "Today's feminism: A brief look at third-wave feminism." Being Feminist. Accessed 3 July 2018. https://bit.ly/2jJwzVO

Freire, Paul. 2005. Pedagogy of the oppressed. New York; Continuum.

Goldman, Karen L. 2010. "Maxine Greene: Influences on the life and work of a dynamic educator." Journal of Educational Controversy 5(1): 1-9.

Goodman, Jesse. and Julie Teel. 1998. "Maxine Greene, democratic community, and education." In The passionate mind of Maxine Greene: 'I am--not yet', edited by William F. Pinar, 59-75. New York: Routledge.

Grant, Carl A. \& Christine Sleeter, E. 1985. "The Literature on Multicultural Education: review and analysis." Educational Review 37 (2): 97-118. doi.org/10.1080/0013191850370202

Grant, Carl A. \& Christine Sleeter, E. 2012. Doing multicultural education for achievement and equity. New York: Routledge.

Greene, Maxine. 1967a. "The Professional Significance of History of Education.” History of Education Quarterly $7(2): 182-190$.

Greene, Maxine. 1967b. "Morals, Ideology, and the Schools: A Foray into the Politics of Education." Educational Theory, 17 (4), 271-288. doi:10.1111/j.1741-5446.1967.tb00317.x

Greene, Maxine. 1968. "Aesthetics, Criticism, and the Work of Literary Art." College English 30 (1): 60-66.

Greene, Maxine. 1971. "Curriculum and Consciousness." Teachers College Record 73 (2): 253-270.

Greene, Maxine. 1977a. "The Artistic. Aesthetic and Curriculum." Curriculum Inquiry 6 (4): 283-296.

Greene, Maxine. 1977b. "Imagination and Aesthetic Literacy." Art Education 30 (6): 14-20.

Greene, Maxine. 1983. "On the American Dream: Equality, Ambiguity, and the Persistence of Rage." Curriculum Inquiry 13 (2): 179-193.

Greene, Maxine. 2000. "The Ambiguities of Freedom." English Education 33 (1): 8-14.

Greene, Maxine. 2007. "Imagination and the healing arts." Maxine Greene Institute. Accessed 12 July 2018. https://maxinegreene.org/uploads/library/imagination_ha.pdf

Greene, Maxine. 2011. "Releasing the Imagination." NJ: Drama Australia Journal 34 (1): 61-70. doi.org/10.1080/14452294.2011.11649524

Gutiérrez, Kris D. ; Jolynn Asato ; Maria Santos, and Neil Gotanda .2002. "Backlash pedagogy: Language and culture and the politics of reform." The Review of Education, Pedagogy, and Cultural Studies 24: $335-351$. doi.org/10.1080/10714410214744

Hawkesworth, Mary. E. 2006. Globalization and feminist activism. New York: Rowman and Littlefield.

Headley, Clevis. 2008. "On the ethics of education: bell hooks' conception of education as the practice of freedom." Wisconsin University Archives, 1-16, https://bit.ly/2KT6XiH

Hooks, Bell. 1965. "Toward a Revolutionary Feminist Pedagogy (Talking Back: Thinking Feminist, Thinking Black)", Chapter 8, page 49, http://people.oregonstate.edu/ vanlondp/wgss320/articles/TowardRevolutionary-Feminist-Pedagogy-bell-hooks.pdf 
Hooks, Bell. 1986. "Sisterhood: Political Solidarity between Women." Feminist Review (23): $125-138$. doi.org/10.1057\%2Ffr.1986.25

Hooks, Bell. 1993. "A Revolution of Values: The Promise of Multi-Cultural Change." The Journal of the Midwest Modern Language Association 26 (1): 4-11.

Hooks, Bell. 1994. Teaching to transgress: Education as the practice of freedom. New York: Routledge.

Hooks, Bell. 1995a. "Feminism: Crying for our Souls." Women and Therapy 17 (1-2): 265-271. doi.org/10.1300/J015v17n01_25

Hooks, Bell. 1995b. "An Aesthetic of Blackness: Strange and Oppositional." Lenox Avenue: A Journal of Interarts Inquiry 1: 65-72. doi:10.2307/4177045

Hooks, Bell. 1995c. "Feminism and Militarism: A Comment." Women's Studies Quarterly 23 (3/4): 58-64.

Hooks, Bell. 1997. "Representing Whiteness in the Black Imagination". In Displacing whiteness: essays in social and cultural criticism, edited by Ruth Frankenberg, 165-179. Durham, USA: Duke University Press.

Hooks, Bell. 2000. "Remembered Rapture: Dancing with Words." JAC 20 (1): 1-8.

Hooks, Bell. 2003. Teaching community: A pedagogy of hope. New York: Routledge.

Jensen, Louise, A. and Marion, N. Allen. 1996. "Meta-synthesis of qualitative findings." Qualitative Health Research 6 (4): 553-560. doi.org/10.1177\%2F104973239600600407

Kisaka, Sella T. and Osman, Ahmed A. 2013. "Education as a quest to freedom: Reflections on Maxine Greene." Journal of Emerging Trends in Educational Research and Policy Studies 4 (2): 338-344.

Lather, Patti. 1987. "The Absent Presence: Patriarchy, Capitalism, and the Nature of Teacher Work." Teacher Education Quarterly 14 (2): 25-38.

Lather, Patti. 1988. "Feminist perspectives on empowering research methodologies." Women's Studies International Forum 11 (6): 569-581. doi.org/10.1016/0277-5395(88)90110-0

Lather, Patti. 1990. "Postmodernism and the human sciences." The Humanistic Psychologist 18 (1): $64-84$. doi.org/10.1080/08873267.19990.9976877

Lather, Patti. 1991. Getting smart: feminist research and pedagogy within/in the postmodern. New York: Routledge

Lather, Patti. 1992. "Critical frames in educational research: feminist and post-structural perspectives." Theory into Practice, 31(2), 87-99. doi.org/10.1080/00405849209543529

Lather, Patti. 1998. "Critical pedagogy and its complicities: a praxis of stuck places." Educational Theory 48 (4): 487-497. doi.org/10.1111/j.1741-5446.1998.00487.x

Lather, Patti. 2004a. "this is your father's paradigm: government intrusion and the case of qualitative research in education." Qualitative Inquiry 10 (1): 15-34. doi.org/10.1177\%2F1077800403256154

Lather, Patti. 2004b. "scientific research in education: a critical perspective." British Educational Research Journal 30 (6): 759-772. doi.org/10.1080/0141192042000279486

Lather, Patti. 2009. "Getting lost: feminist efforts toward a double(d) science. Frontiers." A Journal of Women Studies 30 (1): 222-230. doi.org/10.1353/fro.0.0032

Lather, Patti. 2012. "The ruins of neo-liberalism and the construction of a new (scientific) subjectivity." Cultural Studies of Science Education 7 (4): 1021-1025. doi.org/10.1007/s11422-012-9413-3

Nandini Manjrekar. 2003. "Contemporary challenges to women's education: towards an elusive goal?" Economic and Political Weekly 38 (43): 4577-4582.

Martin, Mart. 2000. The almanac of women and minorities in world politics. Oxford: Westview Press.

Messer-Davidow, Ellen. 2002. Disciplining feminism: from social activism to academic discourse. Duke: Dupe University Press.

Patti Lather's Web Page. 2017. https://u.osu.edu/lather.1/

Rampton, Martha. 2015. "Four waves of feminism." The Magazine of Pacific University 41(2)

Russell, Shona, and Maggie Carey. 2003. "Feminism, therapy and narrative ideas: exploring some not so commonly asked questions." International Journal of Narrative Therapy and Community Work (2): 67-91.

Sandelowskiv Margarete. 1993. "Rigor or rigor mortis: the problem of rigor in qualitative research revisited." Advances in Nursing Science 16 (2): 1-8.

Saugstad, Tone. 2007. "The quality of qualitative teaching: an interview with Patti Lather at the University of Copenhagen." Nordisk Pedagogik 27 (2): 186-196.

Schreiber, R.; Crooks, D. \& Stern, P. N. 1989. Qualitative meta-analysis. In Qualitative Nursing Research: A Contemporary Dialogue, edited by Janice M. Morse, 311-327. London: Sage

Sherwood, Gwen. 1999. "Meta-Synthesis: Merging Qualitative Studies to Develop Nursing Knowledge." International Journal of Human Caring, 3 (1): 37-42. doi:10.20467/1091-5710.3.1.37

Sleeter, Christine. E. 1989. "Multicultural Education as a Form of Resistance to Oppression." The Journal of Education 171 (3): 51-71.

Sleeter, Christine. E. 1994. "Multicultural Education and the American Dream: Race, Class and Gender." Race, Sex and Class $2(1): 31-53$.

Sleeter, Christine. E. 1996. "Multicultural education as a social movement." Theory into Practice 35 (4): $239-$ 247. doi.org/10.1080/00405849609543730 
Sleeter, Christine. E. 2001. "Preparing Teachers for Culturally Diverse Schools Research and the Overwhelming Presence of Whiteness." Journal of Teacher Education 52 (2): 94-106. doi.org/10.1177/0022487101052002002

Sleeter, Christine. E. 2005. Un-standardizing curriculum: Multicultural teaching in the standards-based classroom. New York: Teachers College Press.

Sleeter, Christine. E. 2008. "Teaching for Democracy in an Age of Corporatocracy". Teachers College Record 110 (1): 139-159.

Sleeter, Christine. E. 2011. "An agenda to strengthen culturally responsive pedagogy." English Teaching: Practice and Critique 10 (2): 7-23.

Sleeter, Christine. E. 2014. "Multiculturalism and education for citizenship in a context of neoliberalism." Intercultural Education 25 (2): 1-10. doi.org/10.1080/14675986.2014.886357

Sleeter, Christine. E. 2016a. "Critical Race Theory and the Whiteness of Teacher Education." Urban Education, 1-15, doi.org/10.1177/0042085916668957

Sleeter, Christine. 2018. "A framework to improve teaching in multicultural contexts." Education and selfdevelopment 13 (1): 43-54, doi.org/10.26907/esd13.1.05

Sneider; Allison. 2010. "The new suffrage history: Voting rights in international perspective." History Compass 8 (7): 692-703. doi.org/10.1111/j.1478-0542.2010.00689.x

South End Press Collective, ed. 1998. Talking About a Revolution: Interviews with Michael Albert, Noam Chomsky, Barbara Ehrenreich, bell hooks, Peter Kwong, Winona LaDuke, Manning Marable, Urvashi Vaid and Howard Zinn. Cambridge: South End Press, MA.

Specia, Akello and Ahmed A. Osman. 2015. "Education as a Practice of Freedom: Reflections on bell hooks." Journal of Education and Practice 6 (17): 195-199.

Transcript of Civil Rights Act. 1964. Accessed 3 July 2018. https://bit.ly/2rdbdmv

Walsh, Denis and Soo Downe. 2005. "Meta-synthesis method for qualitative research: a literature review." Journal of Advanced Nursing 50 (2): 204-211. doi.org/10.1111/j.1365-2648.2005.03380.x

Weber, Bruce. 2014. "Maxine Greene, 96, dies; education theorist saw arts as essential." The New York Times, June 4. https://nyti.ms/2Ny13Ft

Wiggins, Grant and Jay McTighe, J. 1998. Understanding by Design. Alexandria, VA: Association for Supervision and Curriculum Development.

Williams, Heather. 2006. "bell hooks Speaks Up. The Sandspur." https://issuu.com/thesandspur/docs/112-17 